\title{
Sustainable Zakat Distribution through Wakalah Contract
}

\author{
Syahmi Haziq Osmera, Hairunnizam Wahid \& Mohd Ali Mohd Noor \\ Universiti Kebangsaan Malaysia
}

\begin{abstract}
This study conveys the importance of the skills element in wakalah contract of zakat distribution practiced in Malaysia to ensure the sustainability of continuous zakat distribution. Skillful representatives will manifest good wakalah and simultaneously increase the quality of zakat distribution. This study employed qualitative methodology which was a semi-structured interview method with the Pelaburan Hartanah Berhad (PHB) Company. The skills element becoming the factor for PHB chosen as a research sample is from the entrepreneurial aspect. PHB distributes zakat in a productive form which is in work capital provision. This can facilitate sustainable economic agenda from the aspect of withdrawing asnaf from poverty and ensuring the zakat payment cycle to continue. The informant of interview is a zakat committee member of PHB directly managing the implementation of wakalah in zakat distribution. The results of the study indicated that the wakalah executed by PHB poses several positive impacts such as wider locality of distribution, positive effect from aspect of communal perception on zakat distribution, and positive impact towards the representatives, which is PHB itself. This study imparts several potential suggestions to improve wakalah system of zakat distribution. This study faced several constraints such as research sample and limited types of zakat wakalah. Future studies are suggested to involve more research samples and investigate wakalah from various types of zakat payment.
\end{abstract}

Keywords: Representative; entrepreneurship; business zakat; distributive locality; communal perception

\section{INTRODUCTION}

Zakat plays an important role in sustainable economic agenda. Zakat refers to some particular wealth obligatory of spending to those who have right on the wealth (Al-Qardawi, 2014). Allah obligates every mukallaf to perform zakat based on His words:

"Truly the alms (zakat) are for the poors, and the needies, and 'amil, and muallaf whose heart are tamed, and the servants, and the debtors, and the warriors of Allah's path ( $f i$ sabilillah), and those who travel." (Qur'an 9:60)
Detailed determination to the eight asnaf contained in the verse indicates that priority should be followed in zakat distribution process (Mahyuddin \& Abdullah, 2011; Hairunnizam et al. 2012). Islamic history has proven that efficiency in management and distribution of zakat fund becomes the factor of country's prosperity until zero poverty can be achieved and socio-economy and even community's life quality can be improved as in the time of Khalifah Umar al-Khattab and Umar Abdul Aziz Caliphates (Ahmed, 2004; Farooq, 2008; Mohsin, 2015; Pg Mohd Faezul et al. 2017). 
In Sustainable Development Goals introduced by United Nations, the first and the second objectives are to end poverty and zero hunger. Sustainable economic agenda is supposed to solve issue of unjust wealth distribution (Sara, Tavassoli \& Heshmati, 2019). From Islamic economic perspective, zakat is a mechanism that should eliminate poverty and ensure sustainable life (Bhuiyan et al. 2012). Among the initiatives applicable is usage of zakat money for micro-entrepreneurial activity (Muller, 2016).

However, there are several issues in zakat distribution that might inhibit the efficiency of distribution process. Among them, Abdul Wahab (1995) \& Azman et al. (2016) stated that weakness of unqualified staffs in zakat institution causes inefficient distribution. Among other factors contributing to ineffieciency of distribution are such as corruption issue (Md Hairi et al. 2011; Nurul Athirah et al. 2018), bureaucracy problem (Rosliza et al. 2015; Mohd Shahril et al. 2016), incomplete data record, lack of workforce and geographical factor (Nurul Athirah, 2018) and zakat surplus which is incompletely distributed to asnaf group (Md Hairi, 2009; Ahmad Fathi et al. 2017) and distribution without following priority order of asnaf (Eza Ellany et al. 2014; Ahmad Fathi et al. 2017; Pg Mohd Faezul, 2019).

Looking at zakat distribution issue that always exists, related personnel should take proactive measure to handle arising issue. Atiah \& Hairunnizam (2017) stated that one of initiatives implementable to improve zakat distribution is through wakalah contract. Nurdiani \& Ekawaty (2015) believed that among the advantages of wakalah in zakat distribution is to strengthen silaturahim (relationship) between muzakki and asnaf and zakat can be distributed to asnaf inaccessible by zakat institution. Islamic Religious Council of Federal Territory (MAIWP) defines wakalah as assignation of authority to zakat payers to distribute zakat money by themselves to eligible asnaf group through refund of an amount of paid money based on lined conditions. Definition of wakalah as authoritative representation complies with the concept of localization which means decentralisation of power in determination of decision (Shah \& Thompson, 2004). Several past studies (Prud'homme, 1995; Shah, 1999; Ivanyna \& Shah, 2010; Gargarella \& Arballo, 2012) paired up the word localisation together with decentralisation indicating that both have the same connotation of meaning. The word decentralisation is defined as transfer of responsibility in planning and management from central administrative institution to lower level of it (Work, 2002). UNDP (2004) stated that decentralisation refers to restructuring of authority so that mutual system of responsibility exists together between central, regional and local administrative institution based on subsidiary principle. Decentralisation concept would connect responsibility network between central institution and sub-national institution either of public or private institution (UNDP, 2004).

Wakalah contract has been applied widely in Islamic financial system such as in banking industry and takaful (Islamic insurance) industry. There are a few studies visualising the advantages of implemented wakalah contract. Al-Bashir and Al-Amine (2013) stated that wakalah contract enables liquidity cycle to operate more efficiently in Islamic banking system. 
From perspective of takaful industry, Khan (2019) pointed that the operational model which is the most efficient and able to fulfill policy holders' and operators' interest is the wakalah-hybrid model. Besides that, wakalah application in marketing which is through assignment of agent makes it more efficient and saves more cost (Hairul Azlan et al. 2004). Puspitasari (2015) said that assignment of agent ensures that transaction between the customers and the operators become more effective. Nadiah 'Aqilah (2013) summarised that agent system poses positive impacts in development and performance of a particular takaful company.

One of wakalah contract pillars is that the representative acts as the receiver of authority/responsibility and the executive. Husen (2004) stated that among the wisdom of wakalah decree is to benefit experience, knowledge and skills of representative in a certain matter. Al-Hammad (2004) stated that among the importance of wakalah contract is to hand over tasks to knowledgeable and experienced representative. Al-Rumi (2011) also implied that the purpose of wakalah is that a less skillful party would hand over tasks to a more skillful representative. Those studies indicate that attributes of skills, knowledge and experience of representative play a role in succeeding wakalah contract. In context of financial system, BNM (2015) stressed that the bank acting as representative should ensure that all related tasks are passed to skillful, qualified and competent staffs. Murni (2018) emphasised that a takaful agent acting as a representative should be knowledgeable especially on the needs of customer. Nadiah 'Aqilah (2013) pointed that skills and expertises of takaful agent contribute greatly to marketing and then affect the performance of takaful company. Hairul Azlan (2004) concluded that agent as mediator plays an important role as various trade transactions such as investment and stock activity depend on skills and expertises of the mediator. On the other hand, Mohamad (2010) stated that takaful agents who do not possess good skills and expertises will fail to convince potential customers and then reduce the productivity of marketing activity.

Based on several mentioned studies, this study summarises that wakalah contract directly correlates with two aspects: localisation concept and representative's skills attribute. As studies regarding localisation have been discussed much in other studies, then this study would not touch in detail on the subject. This study will discuss in depth the second subject which is on representative's skills attribute. As far as of the writer's knowledge, there is no study touching on wakalah in zakat distribution from aspect of representative's skills. Therefore, the study question is to examine the effect of representative's skills to zakat distribution. Conceptual framework of the study is pictured through Figure 1. The figure lines out three pillars in wakalah contract which are: almuwakkil (giver of authority), al-wakeel (agent/representative executing the task) and al-muwakkal fiih (represented matter). Al-muwakkil which is zakat institution hands over authority (localisation/decentralisation) of zakat distribution to al-wakeel (representatives) through wakalah contract. At representative level, this study indicates the need of observing on representative's skills. This is important so that wakalah mechanism would pose positive impacts on al-muwakkal fiih which is zakat distribution. 


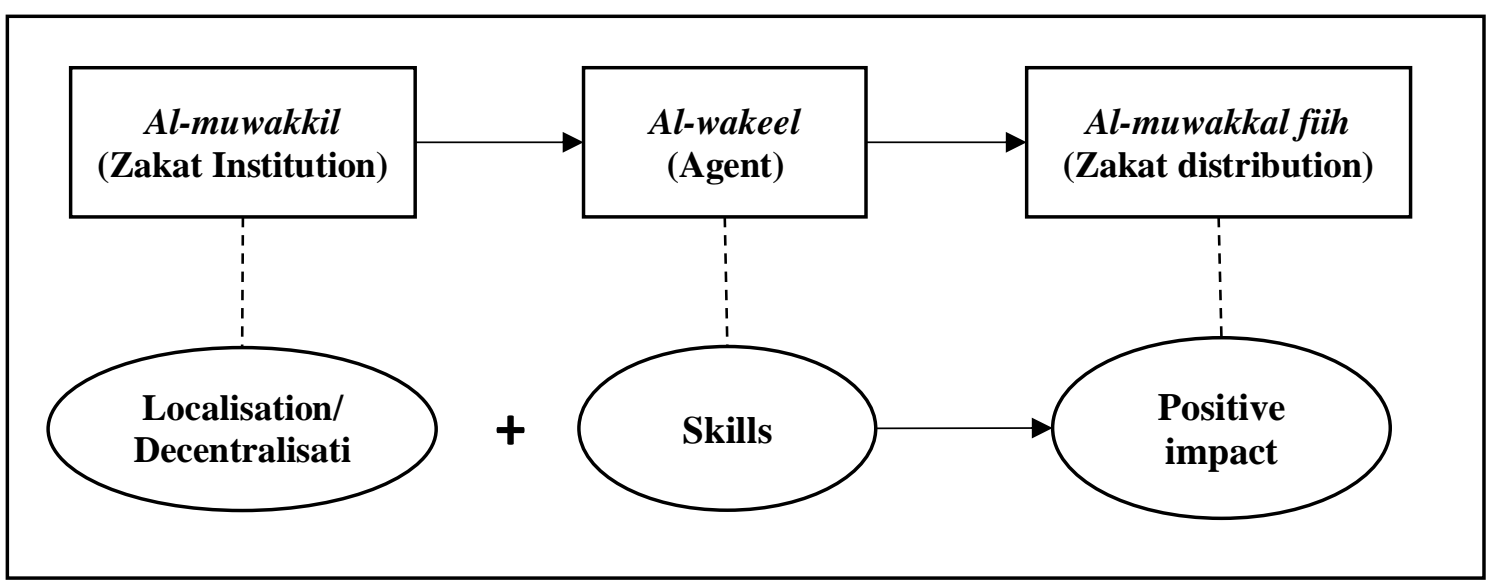

Figure 1. Conceptual Framework of Study

Among companies acting as representatives for MAIWP is Pelaburan Hartanah Berhad (PHB) Company. PHB executes wakalah on zakat paid by Amanah Hartanah Bumiputera (AHB). After AHB side pays zakat to PPZ-MAIWP, PHB side will submit application to PPZ-MAIWP to execute the next wakalah to obtain refund of some of zakat paid by AHB. Then, PHB will distribute the zakat as the representative of MAIWP. Table 1 shows the total of zakat payment fulfilled by $\mathrm{AHB}$ and estimation of refund received by PHB.

Table 1. Zakat payment of AHB \& wakalah estimation of PHB

\begin{tabular}{|c|c|c|c|c|c|c|c|c|c|}
\hline \multirow{2}{*}{ Item } & \multicolumn{9}{|c|}{ Year } \\
\cline { 2 - 10 } & 2012 & 2013 & 2014 & 2015 & 2016 & 2017 & 2018 & 2019 & Average \\
\hline $\begin{array}{c}\text { Zakat } \\
\text { payment } \\
\text { (RM } \\
\text { Million) }\end{array}$ & 1.63 & 1.91 & 2.90 & 2.99 & 3.95 & 2.31 & 3.62 & 3.05 & 2.8 \\
\hline $\begin{array}{c}* \text { Wakalah } \\
\text { estimation } \\
(\mathrm{RM} \\
\text { Million) }\end{array}$ & 0.61 & 0.71 & 1.08 & 1.12 & 1.48 & 0.86 & 1.35 & 1.14 & 1.04 \\
\hline $\begin{array}{c}\text { Annual } \\
\text { change (\%) }\end{array}$ & - & 17.69 & 51.38 & 3.19 & 31.86 & $\begin{array}{c}- \\
41.56\end{array}$ & 56.98 & $\begin{array}{c}- \\
15.56\end{array}$ & 14.85 \\
\hline
\end{tabular}

*Estimations were calculated based on multiplication of $37.5 \%$ by annual zakat payment of AHB.

Source: Annual Report AHB 2012-2019

Figures show that the value of wakalah performed by $\mathrm{PHB}$ reaches millions of ringgit. The highest value was recorded in year 2016 when AHB paid zakat of RM 3.95 million amount and qualifies PHB to distribute zakat of RM 1.48 million. The most drastic annual change occurred in year 2018 which was an increase of $55.98 \%$ compared to the preceding year. The high value of wakalah distribution indicates that PHB plays an important role in zakat distribution process. Wakalah distribution average value of 
RM 1.04 million shows that PHB bears a great responsibility in ensuring that each zakat money is distributed to asnaf. PHB side should possess a systematic strategy that zakat money is distributed totally each year. To achieve the objective, this study sees that skills element plays important role in wakalah in zakat distribution of PHB. Therefore, this study chooses PHB as sample of study by focusing on three research objectives. First, this study will examine the wakalah process of zakat distribution performed by PHB. Second, elaborating skills element of PHB in zakat distribution. Third, explaining positive impacts of wakalah in zakat distribution towards asnaf, PHB Company and MAIWP institution. The second part of this study will be succeeded by literature review, then research methodology, then results of study followed by basic implications and ended with conclusion.

\section{LITERATURE REVIEW}

\section{Sustainable}

Sustainable is translated as concrete; publicly accepted; firm and strong (DBP, 2015). Sustainability concept is introduced as a response to current condition which is unviable in longterm duration (Gibson, 2006). The same study also stated that sustainable agenda is related to process continuously progressing and not halting at certain destination. Objective of sustainable economy is to secure that the needs of generation nowadays are fulfilled without affecting future generations' needs (Farrell, 1995; Caneque, 2000; Chichilnisky, 2010). Robert, Parris \& Leiserowitz (2012) implied that three pillars in sustainability agenda are environment, economy and social. Hopwood, Mellor \& O’Brien (2005) opined that sustainability concept is open to different interpretation according to condition and situation. Wallis \& Valentinov (2017) posed that sustainability should bring long-term benefit and the goodness could develop aligned with current situation.

\section{Zakat distribution}

Aspect of distribution in zakat management is a matter that should be seriously attended. This is because, zakat distribution could bring significant impact to life quality of the needy and poor asnaf (Sanep \& Hairunnizam, 2005; Teh et al. 2016). Besides that, effective zakat distribution will bring positive impact to aggregate spending, labour and capital offer aggregate, economic growth (Norazlina \& Abdul Rahim, 2011), elimination of poverty (Naziruddin et al. 2015; Ayuniyyah et al. 2017), strengthening of social welfare system (Abdullah \& Suhaib, 2011; Raimi et al. 2014; Suprayitno et al. 2017), and consolidation of mustahik spiritual level (Beik \& Arsyianti, 2016). However, zakat distribution system received several criticisms such as that life quality of the needy and poor asnaf is still at the same level despite that zakat institution has entertained asnaf through various forms of developmental and self program (Teh et al. 2016). Muller (2016) criticised zakat distribution which is more focused on preaching activity. He added, in Malaysian context, preaching invites controversy related to sectarian, politics and ideology. Other criticism such as distribution to asnaf who are unknown of either eligible or not has also tarnished public perception to zakat institution (Hairunnizam et al. 2009).

\section{Localisation}


Muhammad Syukri (2006) stated that among the main factors of ineffective zakat distribution is due to connection gap issue between zakat centre and asnaf. The study concluded that by shrinking the connection gap, which is through localisation process, distribution process will be facilitated to be more effective. Hairunnizam et al. (2012) stressed the need for localisation concept through argument that local 'amil can recognize more easily asnaf's background and need in respective place and able to monitor closely the asnaf group. Monitoring is important that asnaf is not just comfortable of receiving zakat but also attempt to change attitude and at the end becomes zakat payers. Hairunnizam et al. (2011) stated that the localisation concept must be initiated by strengthening of mosque institution. The study suggested that zakat centre build branches in mosques due to geographical reason as mosques are closer to the community. The same study also proposed that mosques play their role to educate community regarding religious understanding and effort of improving mental and spiritual level of asnaf to attempt coming out from cocoon of poverty.

\section{Wakalah}

Concept of authoritative assignment in localisation complies with concept of authoritative representation in wakalah. The meaning of wakalah from religious aspect is entrusting or assigning authority to other party in a certain permitted matter (Al-Sa'ad, 2008). There are many differences in scholars' opinion in definition of wakalah. However, majority of scholars agree that definition of wakalah must comprise of three main elements which are party who assigns authority (almuwakkil), representative (al-wakeel) and represented matter (al-muwakkal fiih) (Mohd Napiah, 1975). Shafi'yyah scholars define wakalah as process of authoritative assignment to other party to execute a task that can be substituted by condition that the task is done while the giver of authority is still alive (Nuhyatia, 2013). BNM (2016) defined wakalah as a contract where the giver of authority (muwakkil) assigns authority to other party as agent (representative) to perform certain tasks in matters able of representation, either with charge or not.

Ibnu Qudamah opined that the decree of wakalah is aiming to fulfill human needs (Nugraheni, 2017). Basically, every human should perform his task and responsibility himself. However, sometimes constrain occurs such as being too occupied with plenty of tasks until he needs to seek help from other party (Al-Samid'iy \& Al-Jamili, 2009). Wakalah contract shows that human who is weak in nature, cannot live alone and needs each other to manage life affairs more properly (Nadiah 'Aqilah \& Mohamad, 2013).

Wakalah contract plays an important role in Islamic financial system. In takaful industry, wakalah system is applied through assignment of agent. Agent system can elevate total contributions gained by takaful company as takaful company can open more branches and then ease communication and reduce gap between takaful company and takaful participants (Hairul Azlan et al. 2004). The role of takaful agent in serving customers has a positive and significant relationship with customers' satisfaction level (Zaida Farhana et al. 2018). Meanwhile in capital market industry, Najibah Khairiyah \& Kamaruzaman (2018) stated that wakalah contract is the best alternative to reduce physical 
asset usage in production of short-term sukuk (Islamic bond).

Wakalah contract in zakat distribution is applied by several zakat managerial institution such as MAIWP and Lembaga Zakat Selangor. MAIWP enables company/organisation to apply zakat refund until at $50 \%$ of the total business zakat payment. Zakat can be distributed to all asnafs except 'amil. Atiah \& Hairunnizam (2017) pointed that wakalah contract in zakat distribution had elevated zakat collection especially for business zakat, income zakat and property zakat. The increment was due to community who get their chance of distributing their zakat themselves to the needy and poor group. Meanwhile from zakat payment aspect, Norazira \& Hairunnizam (2019) investigated usage of wakalah contract in zakat payment by BIMB, in which customer/depositor entrusts the bank in zakat fulfillment process. The study stated that wakalah contract is effective in promoting zakat campaign and possibility of zakat collection to increase. The study concluded that wakalah system of zakat payment really helps Islamic socio-economy and brings benefit to all levels of involved parties.

\section{Skills}

The word skill has various definitions. DBP (2008) defined skill as efficiency and ability of performing something. Ashton \& Green (1996) stated that skill refers to knowledge, training, qualification and technical application. Clark (2006) summarised that skill is interpreted as 'know-how' and technique. This means that a skillful person possesses knowledge and masters technique required for handling a particular task. Handel (2008) stated that skill means technical knowledge needed to ensure efficient work performance. Green (2011) said that skill is an individual quality comprising of three attributes: (i) has productive value, (ii) polish-able, such as through training, and (iii) community's recognition, in which community recognise the subject as skill. UKCES (2010) stated that skill can bring maximal impact upon productivity and individual success.

In wakalah contract, AlSami'diy \& Al-Jamili (2009) explained that wakalah contract is decreed to appreciate diversity of human from aspect of skill and ability. Human expert in a certain task can become a substitute/representative for other party to perform the task. As an effect, this wakalah can protect human's right itself more. Qasbah (2017) stated that wakalah contract is important to preserve the concept of justice which is putting the right of something at its place, by meaning of assigning task upon those who are skillful in a certain field.

Summary of study review can be concluded through Figure 2. Issue arising from zakat distribution needs way of solution. Among the steps that can be implemented is through localisation/decentralisation method of zakat distribution matters. The method is compatible with wakalah concept which is entrusting authority to zakat payers to distribute zakat to asnaf by themselves. In wakalah contract, representative's skills play an important role. Reprsentative's skills in zakat distribution later will return to bring positive effect to zakat distribution process. As of the writer's knowledge, there is no study examining in specific the implementative method of wakalah in zakat distribution by any company/organisation acting as representatives in Malaysia. Besides 
that, there is no study of zakat wakalah relating with skills element. Therefore, this study will scrutinise the matter and state the positive effects of wakalah and mention several suggestions for improvement of wakalah in zakat distribution.

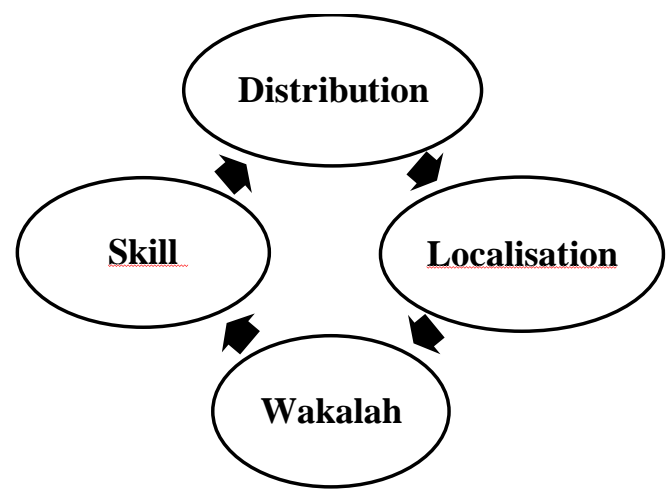

Figure 2. Summary of study review

\section{RESEARCH METHODOLOGY}

Research methodology was in qualitative form encompassing primary data supported by several other sources. This study employed PHB as sample of study. Skills element directly related to PHB is entrepreneurial field. In year 2016, Malaysian government had allocated a fund RM 150 million specific for PHB aiming to boost up Bumiputera's entrepreneurship and business. Meanwhile in year 2020, government allocates an amount of RM 170 million to three companies which are: TEKUN Nasional, SME Bank \& PHB aiming to support development of Bumiputera entrepreneurs. The trust given to $\mathrm{PHB}$ in entrepreneurial developmental program indicates qualification and skills of PHB in entrepreneurial field.

Primary data obtained from semi-structured interviews with Encik Rosmadi Nasir Ahmad who is the Assistant General Manager, Finance \& Operations of PHB. Semi-structural approach based on open ended question is applied widely in interview (Stuckey, 2013; Edwards \& Holland, 2013) as this approach enables the informants to state their opinion and experience in total (Turner, 2010). As there is no concrete answer for the question "what is the appropriate number of informants for interview', then one informant is enough if the information needed is obtainable from the informant (Baker \& Edwards, 2012). Interviews were performed for two times which were on 8 October 2019 and 12 November 2019. The emergent nature of qualitative study can become a factor of the need for second interview to proceed when there are new questions arising and needing for explanation (Jacob \& Fergurson, 2012). The informant is one of the officers in direct involvement with management of zakat wakalah. The informant's capacity as experienced individual in PHB in general and informant's involvement in committee managing zakat wakalah in specific make primary data obtained strong and trusted. Results of interview were recorded and then transcripted for analysis to gain important information to be discussed in results of study.

Besides that, several other materials were also utilised in this study. This study used data and information from written sources such as journal articles, proceeding papers, books, theses and annual reports. This study also gained information from video sources such as recording of programme slot in Al-Hijrah television broadcast directly related to wakalah in zakat distribution of PHB. All sources were used to obtain detailed information related to the study and then strengthen more the results of study. 


\section{RESULTS OF STUDY}

To present results of study more systematically, every result of study is divided into several parts. This study would rewrite some important points of informant's dialogue as the main reference of discussion. The dialogue is conveyed in Italic font form at the beginning of each discussion.

\section{Process of wakalah in zakat distribution in $\mathrm{PHB}$}

1. Types of wakalah

"We distribute business zakat.

Employer zakat is also there, but we only give it to the staffs, as it is not much."

PHB becomes a representative for distribution of zakat paid by AHB. AHB fulfills two types of zakat which are business zakat and employer zakat. Business zakat is a zakat obligatory of fulfillment withdrawn from yield of business property. Employer zakat meanwhile is a zakat obtained from cuts of the staffs' salary. A certain organisation/company can apply for refund until $50 \%$ of total business zakat payment and $37.5 \%$ of total employer zakat. But, based on the performed interviews, PHB only receives $37.5 \%$ total business zakat and $12.5 \%$ from employer zakat. This is because, the original ratio which was at $37.5 \%$ (business zakat) and $12.5 \%$ (employer zakat) has just been raised to $50 \%$ and $37.5 \%$ around the end of year 2019.

For employer zakat category, PHB distributes refunded zakat money specifically to staffs only. Meanwhile for business zakat category, wakalah zakat money is distributed to asnaf of the whole Malaysia and the world. This indirectly ensures the sustainability of zakat distribution to happen due to asnaf scope which is widening to international level. This study will focus to wakalah of business zakat type only. This is because refund ratio received is bigger compared to employer zakat. Therefore, wakalah process for business zakat should be elaborated more deeply. On the other hand, wakalah for distribution of employer zakat will not be discussed in detail in this study.

\section{Zakat committee}

"There is a zakat committee suggesting to higher management on who to give. There are 4 members. A chairman, and 3 members."

Wakalah fund of PHB is managed by a zakat committee comprising of four members, which are a leader and three members. All of them are staffs of PHB. This committee performs three main roles. First, examining application of zakat aid based on guidelines provided by MAIWP. Second, submitting eligible application to higher authority to get approval. Third, after approval is obtained, zakat committee will distribute zakat fund to approved asnaf.

The committee should ensure that refunded zakat money is wholly distributed. Company/organisation who finishes wakalah fund distribution indicates that the institution is committed and proficient in zakat distribution matter. Instead, representative who does not finish zakat distribution will raise several issues such as stockpiling of undistributed zakat amount. While the responsibility of zakat distribution should be born by the representative. Accumulation of undistributed zakat amount will lead to other issue such as accusation that zakat institution is not efficient in zakat distribution. The matter then will pose negative effect to level of trust among the public to the zakat institution itself. 
Hence, the representative should play his role properly so that distribution of zakat wakalah is accomplished to ensure sustainability of zakat distribution always occur every year.

\section{Flowchart}

(1) Those who want to apply for zakat from PHB need to submit application letter to PHB. There is no format of application letter set by PHB. This method eases the applicants as they can write application letter according to situation and need without binding or following certain format that may complicate writing process of application letter. Each application will be evaluated according to guidelines determined by MAIWP. This evaluation process is very important as the zakat money is channeled to asnaf who are really rightful of the zakat money. Zakat money undistributed to rightful asnaf becomes a cruelty to their right. (2) Eligible application will be (3) submitted to higher management for approval. (4) Meanwhile for ineligible application, the process stops at there. (5) If PHB cannot recognise the status of application either eligible or not, (6) the matter will be posed to MAIWP side to get explanation. After MAIWP provides feedback, PHB will reevaluate the application and (7) eligible application will be submitted to higher management, (8) while for ineligible application it stops at there. (9) After higher management approves the posed application, zakat committee personnel will distribute zakat fund to asnaf. (10) Finally, zakat committee will submit report to MAIWP regarding the performed distribution.

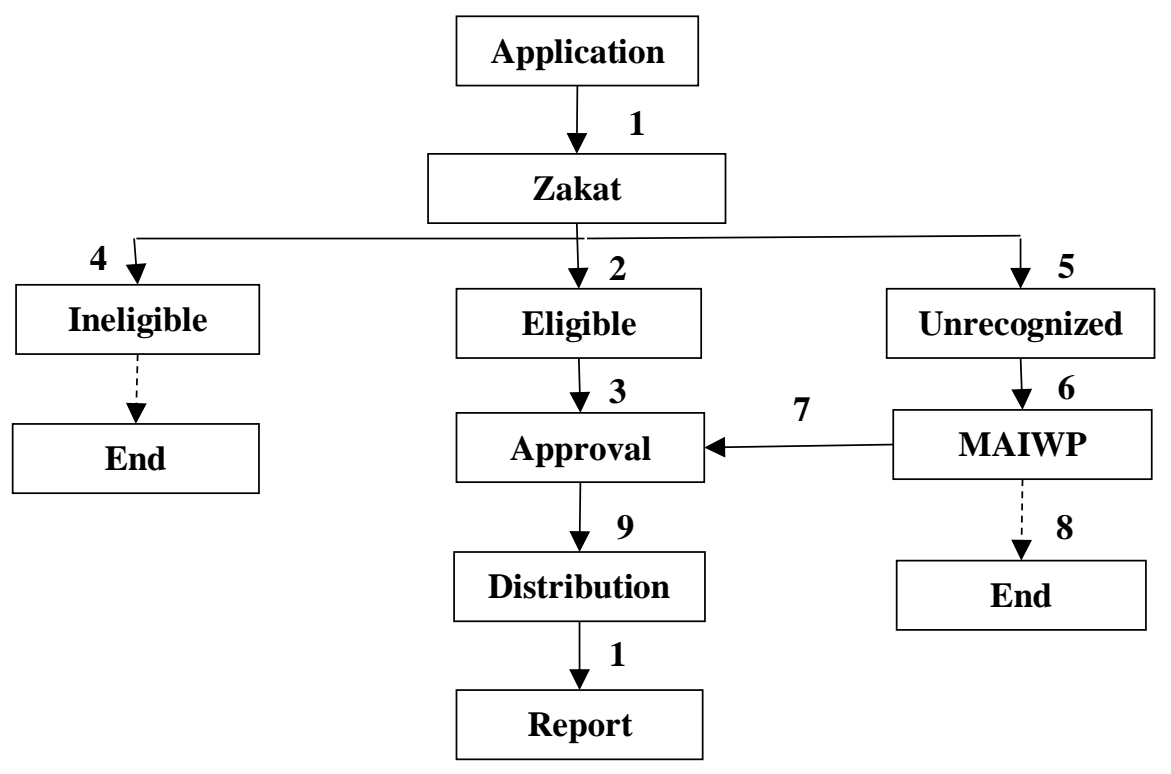

Figure 3. Flowchart of zakat wakalah process by PHB

Source: Interview with PHB officer

\section{Element of skills}

Among the asnafs given priority by PHB are the poor and needy group. MAIWP defines the poor (fakir) as an individual who does not possess any property or job or does receive income from other sources but the total does not reach $50 \%$ from kifayah limit for basic 
needs of himself and his dependents. The needy (miskin) meanwhile means an individual who has job or income exceeding $50 \%$ but does not reach kifayah limit for basic needs of himself and his dependents.

PHB as an investment company should also be equipped with skills in entrepreneurial matters. For the needy and poor asnaf, PHB distributes zakat in productive form which is capital aid either in form of cash or equipment. This capital aid is aiming to help the needy and poor group to change their life towards a better living which is from zakat receiver group to zakat payer group. Zakat aid like this is of longterm goal with hope that the zakat receiver will change status to zakat payer complying with the philosophy of zakat itself (Rosbi et al. 2008). Capital aid encourages self-employment. The concept of self-employment is better than wage-earning as self-employment provides more freedom to individual (Aydin, 2015). Productive zakat distribution can realise the objective of zakat which is to produce independent asnaf and able of sustainable and solid self-sustenance by operating personal business (Putri, Firmansyah \& Hamid, 2019), and then the surplus of business yield can be used to pay zakat (Sumai et al. 2019).

PHB utilises medium of Man Jadda Wajada programme produced by Al-Hijrah television broadcast to distribute the zakat. In conjunction with the meaning of the program "who strives will succeed,' PHB distributes zakat in work capital form to asnaf so that they strive to become successful entrepreneurs. PHB distributes the zakat to the whole Malaysia regardless of operated business type or business location. This action becomes a positive effort especially to facilitate and encourage asnaf so that they themselves put efforts to come out from coccon of poverty. Sustainability from aspect of self-value development within asnaf is also important to ensure that statistics of asnaf household be reduced from year to year.

\section{Positive impacts of wakalah contract}

1. Distribution locality

"Zakat institution has a lot of constraints to get asnaf, the collection is a lot, but the area is small. We have no limit, able to provide even outside of region."

PHB as a representative can distribute zakat without being restricted to only certain places. PHB can distribute zakat to any eligible asnaf from all places even though zakat collection is only from Federal Territory. This situation can bring positive impact to distribution as MAIWP receives total collection that increases each year. In year 2019, total collection of zakat by MAIWP reached RM 682 million. The value was an increment of $4.7 \%$ compared to year 2018 recording total collection of RM 651 million. The amount if only distributed to asnaf in Federal Territory might be complicated as the area is limited. Therefore, the wakalah mechanism performed enables MAIWP through representatives, to distribute zakat to other places so that distributive locality becomes wider and distribution can be executed more quickly. Besides asnaf within the country, PHB also distributes zakat overseas such as to Palestine. The distribution is performed through application made by recognised non-governmental organisations (NGO) such as Aman Palestin who applies for zakat from PHB to distribute to asnaf in Palestine. This situation indicates that wakalah contract makes distributive locality widens much and becomes 
more effective until to level of overseas asnaf and at the same time ensures sustainability of zakat distribution to occur continuously.

\section{Community's perception}

"People see where zakat money is spent. If not, people will assume that it is only for MAIWP."

Issue of community's perception to zakat distribution has been discussed a lot in many studies. Complaints on zakat institution regarding collection and distribution process will affect community's confidence and then bring to issue of refusal of zakat payment (Sanep \& Hairunnizam, 2005; Ahmad Hidayat \& Saidatul Badrul, 2014; Ismail \& Masturah, 2014). When wakalah is performed by PHB through reality program such as Man Jadda Wajada, audiences in which majority of them are from Muslims in the whole country can witness how zakat money is benefited. Program like this will repel bad accusations directed to zakat institution. This is because the audiences could experience by themselves the life difficulty undergone by asnaf and feel the happiness of asnaf after PHB distributes zakat money to them. Previously, the community are only told that zakat money is distributed to asnaf without witnessing in live the role of zakat in assisting asnaf. Through reality program like this, community could witness themselves the role of zakat and then become more concerned and emphatic to asnaf group and simultaneously will increase community's awareness to perform zakat. This clearly shows that through wakalah contract, sustainability of zakat distribution occurs and is very effective.

\section{Effects to PHB}

"People see that the $A H B$ fund is fulfilled as zakat. $A H B$ unit holders are throughout the whole Malaysia. So, if they pay zakat to MAIWP only meaning that only asnaf of Federal Territory will get. But when wakalah is performed, it can be distributed to the whole Malaysia."

Alongside with community's awareness to obligation of zakat, company/organisation should also concern on zakat payment. Zakatpaying investment institution has its own added value as Muslim community concerning of zakat obligation should be more prone to choose investing in zakat-paying investment fund. Zakat wakalah process performed by PHB becomes an important indicator to show that AHB investment fund pays zakat upon business yield. This will attract Muslim investors as the investors do not need to think of zakat matter yielding from their investment in AHB.

AHB unit holders consist of Bumis community throughout the whole country. When PHB executes zakat wakalah, AHB unit holders can see that the zakat money is benefited by asnaf from the whole country. If PHB side does not take initiative to become a representative, investors will assume that AHB investment zakat is paid to PPZ-MAIWP and then distributed only to asnaf in Federal Territory. Through wakalah, the assumption can be avoided and then becomes an added value to AHB to attract more investors on account of zakat distributive locality benefited to the whole country.

From a wider perspective, increase in number of investors will elevate profit potential of $\mathrm{AHB}$ and then increase potential of AHB's business zakat total. The increment will increase PHB wakalah value and then enables 
PHB to help more asnaf. Besides that, profit increase also becomes a maslahah to Muslim community as PHB is a company focusing on Bumiputera in which Muslims represent $88.67 \%$ of the whole Bumis. Then PHB's profit increase indirectly will benefit many Muslim investors and raise up image of company managed by Muslims. This indicates that the sustainability of zakat distribution through wakalah contract can uphold image of institution and then ensure sustainability of the business to continue through profit increase and others.

\section{DISCUSSION AND BASIC IMPLICATIONS}

This study discusses application of wakalah in zakat distribution has several advantages especially the one performed by PHB. This study opined that wakalah of zakat distribution should be continued and strengthened in several aspects. This is important as to increase more positive effect of wakalah in zakat distribution as stated in the study by Nurdiani \& Ekawaty (2015) and Atiah \& Hairunnizam (2017). Among the improvements implementable is from aspect of selection for company/organisation to become representative. At early stage of wakalah introduction, it is necessary for MAIWP of not putting strict conditions to become a representative. This is to attract community especially organisation/company to wakalah mechanism. After the 'introductory phase', this study believes that MAIWP should put more specific criteria for company/organisation who wants to become a representative. This is important as the ratio refunded would be big. Therefore, several conditions should be determined with purpose of avoiding problems such as issue of refund of wakalah money undistributed according to determined duration.

Among suggested criteria
applicable is that every organisation/company who wants to become a representative should have a plan regarding the distribution to be performed. The plan is important so that from early stage of application, all companies already have target of distribution to be executed. This study suggests that the target is related to skills or field of the company itself. This aligns with the goal of wakalah contract decree which is to assign authority to a representative who possesses advantages from skills aspect (Al-Hammad, 2004; Husen, 2004; AlSamid'iy \& Al-Jamili, 2009; Al-Rumi, 2011). For example, PHB as an investment company well-versed of entrepreneurship distributes zakat in work capital form to asnaf who are interested of involving with business.

Wakalah of zakat distribution in productive form can contribute to sustainable economic agenda. This is because, productive zakat will open way for asnaf to get out from poverty through entrepreneurial sector. Yield from operated business can be used to sustain self and family sustainability and continuously (Putri, Firmansyah \& Hamid, 2019). Then, surplus of business revenue can be utilised to develop the business further and enable asnaf to become zakat payers. This complies with the sustainability concept which is to fulfill needs of current generation without sacrificing future generations (Farrell, 1995; Caneque, 2000; Chichilnisky, 2010). Asnaf generation receiving productive zakat then will re-contribute to zakat fund to help the next asnaf generation. 
After going through the phase where the representative should present their plan in zakat distribution, then MAIWP can recognise target or field which is void and need to be improved. After that, MAIWP does not only offer wakalah policy openly, instead MAIWP should put specific criteria that the party who becomes a representative should be proficient and target the void field to handle arising problems. For example, if zakat distribution in education still could not produce excellent students that can re-contribute to community, then MAIWP will offer specific refund policy to proficient representative or focus distribution to education only so that the problem can be overcome.

To realise this suggestion, representatives especially company/organisation should have optimal workforce from quantitative and qualitative aspect. The number of unit members managing zakat wakalah should be adequate to perform screening of received zakat application. Number of members incompatible with received application quantity might affect screening process and burden zakat unit. Zakat unit members should also be proficient in drafting plan for target of zakat distribution. Distribution suggestion according to skills begins with appointment of zakat unit members proficient in a certain field. Skills of zakat unit members might be incompatible with main activity of company/organisation. However, distribution process according to skills of zakat unit members can still be classified as wakalah of zakat distribution according to skills, which are the skills of zakat unit members. Then, this study suggests that company/organisation does not just distribute zakat as a one-off, instead performs follow-up action such as updating information regarding asnaf and providing guidance according to asnaf's need. For example, for asnaf given work capital, their sales data should be examined and then they are given training or advisory service to improve the asnaf's performance.

\section{CONCLUSION}

Wakalah contract is an initiative of great potential for improvement of zakat distribution quality. PHB as a model company participating in wakalah of zakat distribution has shown several advantages of the contract application such as from aspect of wider distributive locality, positive perception of community and positive effects towards PHB institution itself. Based on distributive method applied by PHB, this study presents several suggestions seen able to refine the potential of wakalah contract and consequently pose positive impacts to zakat distribution. Among the suggestions is that the representative should have a particular plan or target in distribution. To appreciate the wisdom of wakalah decree which is to assign to proficient party, this study suggests that distribution target is related to the main business of the company itself such as PHB as an investment company distributes zakat in entrepreneurial field which is through productive zakat. Productive zakat will support sustainable economic agenda by encouraging asnaf to come out from cocoon of poverty. Besides that, representative should also take proactive action in providing guidance and support to asnaf and not just becoming a mediator in zakat distribution process. This study contains several constraints such as investigating only wakalah of PHB business zakat. Other study can be performed to study 
wakalah of other zakat payment type such as employer zakat which is also performed by PHB. Other constraint is from aspect of limited sample of study. Future studies can involve more samples to gain a comprehensive picture. This study suggests that a quantitative study be performed to support findings and suggestions of this study.

\section{REFERENCES}

Abdul Wahab, M., Al-Junaid, S.A.H., Omar, M.A., Ghazali, A., Osman, J. \& Arif, M. 1995. Case study: Malaysia. Dlm. El-Ashker, A.A.F. \& Haq, M.S (pnyt). Institutional Framework of Zakah: Dimensions and Implications, hlm. 297-378. Jeddah: Islamic Research \& Training Institute.

Abdullah, M. \& Suhaib, A.Q. 2011. The Impact of Zakat on Social life of Muslim Society. Pakistan Journal of Islamic Research 8: 85-91.

Ahmad Fathi, A., Hairunnizam, W. \& Mohd Ali, M.N. 2017. Kecekapan Pengurusan Kewangan Dan Pengurusan Agihan Zakat: Kajian Terhadap Majlis Agama Islam Johor. UMRAN International Journal of Islamic and Civilizational Studies 4(3): 52-66.

Ahmad Hidayat, B. \& Saidatul Badrul, M.S. 2014. Pentadbiran Zakat dan Kesedaran Masyarakat Islam Membayar Zakat di Daerah Kota Belud Sabah. Sains Humanika 2(1): 125-134.

Ahmed, H. 2004. Role of Zakah and Waqaf in Poverty Alleviation. Jeddah: Islamic Development Bank Group.

Amanah Hartanah Bumiputera. Laporan Tahunan 2012.

Amanah Hartanah Bumiputera.
Laporan Tahunan 2013.

Amanah Hartanah Bumiputera.

Laporan Tahunan 2014.

Amanah Hartanah Bumiputera. Laporan Tahunan 2015.

Amanah Hartanah Bumiputera. Laporan Tahunan 2016.

Amanah Hartanah Bumiputera. Laporan Tahunan 2017.

Amanah Hartanah Bumiputera. Laporan Tahunan 2018.

Amanah Hartanah Bumiputera. Laporan Tahunan 2019.

Ashton, D. \& Green, F. 1996. Education, Training and the Global Economy. Aldershot: Edward Elgar.

Atiah, A. \& Hairunnizam, W. 2017. Kontrak Wakalah dalam Agihan Zakat: Kajian di Majlis Agama Islam Wilayah Persekutuan. Dlm. Hairunnizam, W., Mohd Ali, M.N., Adibah, A.W. \& Muhammad Tajuddin, A.R (pnyt). Pengurusan Zakat Di Malaysia Satu Pendekatan Analisis Gelagat, hlm. 171-187. Bangi: Pusat Penyelidikan Ekonomi dan Kewangan Islam (EKONISUKM).

Aydin, N. 2015. Islamic social business for sustainable development and subjective wellbeing. International Journal of Islamic and Middle Eastern Finance and Management 8(4):491-507.

Ayuniyyah, Q., Huq Pramanik, A., Md Saad, N. \& Irwan Ariffin, M. 2017. The Comparison between Consumption and Productionbased Zakat Distribution Programs for Poverty Alleviation and Income Inequality Reduction. International Journal of Zakat 2(2): 11-28.

Azman, A.R., Mohamad, Y.A.B., Mohammad, N.N., Mahdhir, A., Ahmad, A.M.F. \& Mohd, F.A.B. 
2016. Program Usahawan Bagi Memperkasakan Ekonomi Golongan Asnaf: Pemantauan Dari Aplikasi Myema. Jurnal Pengurusan dan Penyelidikan Fatwa 7: 29-38.

Baker, S.E. \& Edwards, R. 2012. How many qualitative interviews is enough? National Centre for Research Methods Review Paper.

Bank Negara Malaysia. 2015. Wakalah Concept Paper.

Bank Negara Malaysia. 2016. Wakalah.

Al-Bashir, M. \& Al-Amine, M. 2013. Managing Liquidity Risk in Islamic Finance. Dlm. Ahmed, K.H. (pnyt). Contemporary Islamic Finance: Innovations, Applications, and Best Practices, hlm. 121-146. New Jersey: John Wiley \& Sons, Inc.

Beik, I.S. \& Arsyianti, L. 2016. Measuring Zakat Impact On Poverty And Welfare Using Cibest Model. Journal of Islamic Monetary Economics and Finance 1(2): 141-160.

Bhuiyan, A.B., Siwar, C., Islam, A. \& Rashid, M. 2012. The Approaches of Islamic and Conventional Microfinancing for Poverty Alleviation and Sustainable Livelihood. American Journal of Applied Sciences 9(9): 1385-1389.

Caneque, F.C. 2000. Social Standards: Measuring and Reporting Corporate Social Performance. Corporate Reputation Review 3(2): 145-163.

Chichilnisky, G. 2010. Sustainable development: equal treatment of the present and the future? Int. J. Green Economics 4(4): 346-359.

Clark, L. \& Winch, C. 2006. A European skills framework? - but what are skills? Anglo-Saxon versus German concepts. Journal of Education and Work 19(3):
255-269.

Dewan Bahasa \& Pustaka. 2008. Kamus pelajar bahasa Malaysia. Kuala Lumpur: Dewan Bahasa \& Pustaka.

Dewan Bahasa \& Pustaka. 2015. Kamus Pelajar Bahasa Malaysia Edisi Kedua. Kuala Lumpur: Dewan Bahasa \& Pustaka.

Edwards, R. \& Holland, J. 2013. What is qualitative interviewing? London: Bloomsbury.

Eza Ellany, A.L., Mohd Rizal, P. \& Mohamat Sabri, H. 2014. Prestasi Kecekapan Agihan Kewangan dan Bukan Kewangan di Kalangan Institusi Zakat di Malaysia. Jurnal Ekonomi Malaysia 48(2): 51 - 60.

Farooq, M.O. 2008. The challenge of poverty and the poverty of Islamic economics. Journal of Islamic Economics, Banking and Finance 4(2): 35-58.

Farrell, A. 1995. Sustainability theory and the design of knowledge tools. Proceedings 1995 Interdisciplinary Conference: Knowledge Tools for a Sustainable Civilization. Fourth Canadian Conference on Foundations and Applications of General Science Theory.

Gargarella, R. \& Arballo, G. 2012. Federalism and fiscal federalism: the emergence and distortion of the centro-federalist constitutional model in its political and fiscal manifestations. Dlm. Brosio, G. (pnyt). Decentralization and Reform in Latin America: Improving Intergovernmental Relations, hlm 13-37. Cheltenham: Edward Elgar Publishing Limited.

Gibson, R.B. 2006. Sustainability assessment: basic components of a practical approach. Impact 
Assessment and Project Appraisal 24(3): 170-182.

Green, F. 2011. What is Skill? An InterDisciplinary Synthesis. Centre for Learning and Life Chances in Knowledge Economies and Societies Research Paper No 20.

Hairul Azlan, A. 2004. Al-Wakalah and Customers' Preferences toward It: A Case Study of Two Takaful Companies in Malaysia. The American Journal of Islamic Social Sciences 22(1): 28-49.

Hairul Azlan, A., Saiful Azhar, R. \& Hafiz Majdi, A.R. 2004. Al Wakalah And Its Impact On The Growth And Performance Of Takaful Companies: A Malaysia Case. The European Journal of Management and Public Policy 3(1): 84-119.

Hairunnizam, W., Radiah, A.K. \& Sanep, A. 2011. Localization of Zakat Distribution and The Role of Mosque: Perceptions of Amil and Zakat Recipents in Malaysia. International Zakat Forum 2011.

Hairunnizam, W., Sanep, A. \& Radiah, A.K. 2009. Pengagihan zakat oleh institusi zakat di Malaysia: Mengapa Masyarakat Islam Tidak Berpuashati? Jurnal Syariah 17(1): 89-112.

Hairunnizam, W., Sanep, A. \& Radiah, A.K. 2012. Cadangan penyetempatan pengagihan zakat di Malaysia: Adakah amil sudah bersedia? Jurnal Ekonomi Malaysia 46(2): 17-27.

Al-Hammad, H.A. 2004. 'Aqd AlWakālä̈ fi Al-Fiqh Al-Islami wa Tațbiqātuhu fi Kitābāt Al-'Adl bi Al-Mamlakä̈ Al-'Arabiyyä̈ AlSa'udiyyä̈. Dlm. Ministry of Justice Saudi Arabia. Kitābä̈ Al'Adl Al-Thānyyä̈, hlm. 130-166. Riyadh: Ministry of Justice.

Handel, M.J. 2008. Measuring Job
Content: Skills, Technology, and Management Practices. Institute for Research on Poverty Discussion Paper No 1357.

Hopwood, B., Mellor, M. \& O'Brien, G. 2005. Sustainable Development: Mapping Different Approaches. Sustainable Development 13: 3852.

Husen, A.H.M. 2004. Al-wakālä̈ fi AlŠhari'ä̈ Al-Islamyyä̈. Kaherah: Al-Alukah.

Ismail, H.A. \& Masturah, M. 2014. The Efficiency of Zakat Collection and Distribution: Evidence From Two Stage Analysis. Journal of Economic Cooperation and Development 3(35): 133-170.

Ivanyna, M. \& Shah, A. 2010. Decentralization (Localization) and Corruption New Crosscountry Evidence. World Bank Policy Research Working Paper 5299.

Jabatan Perangkaan Malaysia. 2011. Taburan Penduduk Dan Ciri-Ciri Asas Demografi 2010.

Khan, H. 2019. A Nontechnical Guide on Optimal Incentives for Islamic Insurance Operators. Journal of Risk and Financial Management 12(3): 1-14.

Kementerian Kewangan Malaysia. 2015. Bajet 2016.

Kementerian Kewangan Malaysia. 2019. Belanjawan 2020.

Jacob, S.A. \& Furgerson, S.P. 2012. Writing Interview Protocols and Conducting Interviews: Tips for Students New to the Field of Qualitative Research. The Qualitative Report 17(6): 1-10.

Mahyuddin, H.AB. \& Abdullah, H.A.G. 2011. Towards Achieving the Quality of Life in the Management of Zakat Distribution to the Rightful Recipients (The Poor and Needy). 
International Journal of Business and Social Science 2(4): 237-245.

Md Hairi, M.H. 2009. Keberkesanan Sistem Agihan Zakat: Suatu Pandangan Awal. Laporan kajian. Universiti Utara Malaysia.

Md Hairi, M.H., Ram, A.J.S. \& Azizi, H.H. 2011. Kod Etika Amil Zakat: Satu Perspektif Islam. International Islamic Development Management Conference (IDMAC 2011) No. 60.

Mohamad, A.H., Nik, M.A.R., Noor, I.Y. \& Rubayah, Y. 2010. Performance Determination Model Of Human Capital Development For Takaful Industry In Malaysia. The Journal of Knowledge Economy \& Knowledge Management 5(2): 141-151.

Mohd Napiah, M.D. 1975. The Theory Of The Contract Of Agency (Al Wakalah) In Islamic Law. Tesis Dr. Fal. Department of Law and Public Administration, Glasgow Caledonian University.

Mohd Shahril, A.R., Abdul Rahim, R. \& Muhammad Farid, M.E. 2016. Zakat Management in Malaysia: A Review. American-Eurasian Journal of Scientific Research 11(6): 453-457.

Mohsin, M.I.A. 2015. Potential Of Zakat In Eliminating Riba And Eradicating Poverty In Muslim Countries \{Case Study: Salary Deduction Scheme Of Malaysia\}.International Journal of Islamic Management and Business 1(1): 40-63.

Muhammad Syukri, S. 2006. Lokalisasi Zakat: Satu Cadangan Teoritis. Dlm. Abdul Ghafar, I. \& Hailani, M.T. (pnyt). Zakat Pensyariatan Perekonomian dan Perundangan, hlm. 213-227. Bangi: Penerbit
Universiti Kebangsaan Malaysia. Muller, D.M. 2016. From Consultancy to Critique: The "Success Story" of Globalized Zakat Management in Malaysia and its Normative Ambiguities. Globalizations 14(1): 81-98.

Murni, Y. 2018. Implementation of Relationship Marketing in Takaful through Wakalah Business Model. International Journal of Academic Research in Business and Social Sciences 8(11): 98-107.

Nadiah 'Aqilah, M.A. \& Mohamad, A.H. 2013. Shariah Compliance of Wakalah Concept in Takaful Operation: A Case Study of A Takaful Operation in Malaysia. Tazkia Islamic Finance and Business Review 8(2): 210-235.

Najibah Khairiyah, S. \& Kamaruzaman, N. 2018. Analisis terhadap Aset Sandaran Alternatif bagi Penerbitan Sukuk Jangka Pendek oleh International Islamic Liquidity Management (IILM). Jurnal Pengurusan 54(2018): 181-188.

Naziruddin, A., Aliah, M.D. \& AlMalkawi, H.N. The Effectiveness Of Zakat In Alleviating Poverty And Inequalities: A Measurement Using A Newly Developed Technique. Humanomics 31(3): 314-329.

Norazira, S. \& Hairunnizam, W. 2019. Aplikasi Konsep Wakalah Dalam Pembayaran Zakat Simpanan: Kaiian Di Bank Islam Mataysia Berhad (BIMB). Jurnal Pengurusan dan Penyelidikan Fatwa 17(2): 333-354.

Norazlina, A.W. \& Abdul Rahim, A.R. 2011. A framework to analyse the efficiency and governance of zakat institutions. Journal of Islamic Accounting and Business 
Research 2(1): 43-62.

Nugraheni, D.B. 2017. Analisis Fatwa Dewan Syariah Nasional Tentang Wakalah, Hawalah, dan Kafalah Dalam Kegiatan Jasa Perusahaan Pembiayaan Syariah. Media Hukum 24(2): 124-136.

Nuhyatia, I. 2013. Penerapan Dan Aplikasi Akad Wakalah Pada Produk Jasa Bank Syariah. Jurnal Ekonomi Dan Hukum Islam 3(2): 94-116.

Nurdiani, P. \& Ekawaty, M. 2015. Efektivitas Pendistribusian Zakat Profesi Pegawai Negeri Sipil Melalui Sistem Wakalah Di Kementerian Agama Kota Malang Ditinjau Dari Fiqh Zakat. Jurnal Ilmiah Mahasiswa Fakultas Ekonomi dan Bisnis 3(2): 1-18.

Nurul Athirah, M.A., Muhammad Saiful, H.H. \& Roslina, H. 2018. Faktor Yang Mempengaruhi Jumlah Agihan Dana Zakat Melebihi Jumlah Kutipan Pada Tahun 2014 Hingga 2016 Di Maipk: Satu Analisa. Jurnal 'Ulwan 1(1): 1-10.

Pg Mohd Faezul, F.A.O., Hairunnizam, W. \& Mohd Ali, M.N. 2017. Kecekapan Pengurusan Kewangan Dan Agihan Zakat: Kajian Di Majlis Ugama Islam Sabah ( MUIS ). Jurnal Syariah 25(3): 415-452.

Pg Mohd Faezul, F.A.O. 2019. Analisis Prestasi Kecekapan Agihan Zakat: Kajian Di Tabung Baitulmal Sarawak. Labuan E-Journal Of Muamalat And Society (1): 60-78.

PPZ MAIWP. Ringkasan Laporan Zakat 2019. https://drive.google.com/file/d/1tl CNOFUgk4AUvd9TmSFK35gNY n8uGzf0/view. [28 June 2020]

PPZ MAIWP. Wakalah. https://www.zakat.com.my/infozakat/wakalah/. [23 November
2019]

Prud'homme, R. 1995. The Dangers of Decentralization. The World Bank Research Obserer 10(2): 201-220.

Puspitasari, N. 2015. Hybrid Contract And Funds Efficiency Management Of Islamic General Insurance Company (Study In Indonesia). Social and Behavioral Sciences 211 (2015): 260 - 267.

Putri, S.A.M., Firmansyah, E.J.R. \& Hamid, H. 2019. The mustahiq empowerment model: a collaboration between sharia bank and opz in optimizing zakat funds. Humanities \& Social Sciences Reviews 7(2): 276-281.

Al-Qardawi, Yusuf. 2014. Fiqh alzakä̈t. Ed. Ke-16. Beirut: Resalah Publishers.

Qasbah, Y. 2017. Al-Wakālah fi alKhūsūmä̈ bayna al-Šharia'h wa al-Qanūn. Tesis. S. Sn. Sos. University Echahid Hamma Lakhdar.

Raimi, L., Patel, A. \& Adelopo, I. 2014. Corporate social responsibility, Waqf system and Zakat system as faith-based model for poverty reduction. World Journal of Entrepreneurship, Management and Sustainable Development 10(3): 228-242.

Robert, K.W., Parris, T.M., Leiserowitz, A.A. 2012. What is Sustainable Development? Goals, Indicators, Values, and Practice. Environment: Science and Policy for Sustainable Development 47(3): 8-21.

Rosbi, A.R., Sanep, A. \& Hairunnizam, W. 2008. Perlaksanaan Bantuan Modal Zakat: Analisis Perbandingan. Working Paper in Islamic Economics and Finance 0814.

Rosliza, R. @ R., Ibrahim, H., Sanep, A., Abdul Basir, H.H. \& Shofian, 
H.A. 2015. Inovasi dalam Pengurusan Zakat di UPSI: Kesannya Terhadap Kepuasan Asnaf dalam Kalangan Pelajar. Jurnal Perspektif (7)1: 101-112.

Al-Rumi, M.S.S. 2011. Al-Wakālä̈ AlHașriyä̈ wa 'A'lāqatuhā bi AlIhtikār fi Al-Fiqh Al-Islamiy. Tesis. S. Sn. Sos, Fakulti Syariah \& Undang-Undang, The Islamic University, Gaza.

Al-Sa'ad, Ahmad. 2008. Fiqh alMu 'amalāt. Irbid: Dar-AlKetab Publishers.

Al-Samid'iy, Z.H. \& Al-Jamili, A.I.A. 2009. Al-Wakālä̈ bi al-Kh̆ūșūmä̈ fi al-Fiqh al-Islāmi wa al-Qānūn al-'Irāqi. Tikrit Uniersity Journal For Rights 1(2): 342-378.

Sanep, A. \& Hairunnizam, W. 2005. Persepsi Agihan Zakat dan Kesannya terhadap Pembayaran Zakat Melalui Institusi Formal. Jurnal Ekonomi Malaysia 39: 5369.

Sara, A.S., Tavassoli, M., Heshmati, A. 2019. Assessing the sustainability of high-, middle-, and low-income countries: A network DEA model in the presence of both zero data and undesirable outputs.. Sustainable Production and Consumption 21: 78-91.

Shah, A. 1999. Balance, Accountability, and Responsiveness: Lessons About Decentralization. World Bank Policy Research Working Paper 2021.

Shah, A. \& Thompson, T. 2004. Implementing Decentralized Local Government: A Treacherous Road With Potholes, Detours And Road Closures. World Bank Policy Research Working Paper 3353.

Stuckey, H.L. 2013. Three types of interviews: Qualitative research methods in social health. Journal of Social Health and Diabetes 1(2): 56-59.

Sumai, S., Mutmainnah, A.N., Nurhamdah \& Arsyad, M. 2019. Role of zakat in poverty reduction and food security. IOP Conference Series: Earth and Environmental Science 343.

Suprayitno, E., Aslam, M. \& Harun, A. 2017. Zakat and SDGs: Impact Zakat on Human Development in the Five States of Malaysia. International Journal of Zakat 2(1): 61-69.

Teh, S.T., Aza, S.A. \& Noraini, S. 2016. Impak Agihan Zakat Terhadap Kualiti Hidup Asnaf Di Selangor. 2nd International Conference on Economics \& Banking, hlm. 226-237.

Turner, D. W. (2010). Qualitative Interview Design: A Practical Guide for Novice Investigators.The Qualitative Report 15(3): 754-760.

UK Commision for Employment \& Skills. 2010. Skills for Jobs: Today and Tomorrow.

United Nation Development Programme (UNDP). 2004. Decentralised Governance for Development: A Combined Practice Note on Decentralisation, Local Governance and Urban/Rural Development.

Wallis, S.E. \& Valentinov, V. 2017. What is Sustainable Theory? A Luhmannian Perspective on the Science of Conceptual Systems. Foundations of Science 22: 733747.

Work, R. 2002. Overview Of Decentralisation Worldwide: A Stepping Stone To Improved Governance And Human Development. Philippine Journal 
of Public Administration 46(1): 124.

Zaida Farhana, M.S., Mohd Zulkifli, M. \& Nur Haiza, M.Z. 2018. Determinants of customer satisfaction in Takaful (islamic insurance) services in Malaysia. Jurnal Pengurusan 54(2018): 205-211.

Syahmi Haziq Osmera

Center for Sustainable \& Inclusive

Development, Faculty of Economics \& Management

Universiti Kebangsaan Malaysia

Hairunnizam Wahid

Center for Sustainable \& Inclusive

Development, Faculty of Economics \&

Management

Universiti Kebangsaan Malaysia

Mohd Ali Mohd Noor

Center for Sustainable \& Inclusive

Development, Faculty of Economics \&

Management

Universiti Kebangsaan Malaysia 
